Southern Illinois University Edwardsville SPARK

SIUE Faculty Research, Scholarship, and Creative Activity

2017

\title{
A Turn to Realism and Humanism from Propaganda: Chinese Photojournalism Practices between 1976 and 1988
}

Shi Li

shli@siue.edu

Follow this and additional works at: http://spark.siue.edu/siue_fac

Part of the Asian History Commons, Chinese Studies Commons, Cultural History Commons, Journalism Studies Commons, and the Visual Studies Commons

\section{Recommended Citation}

Li, Shi, "A Turn to Realism and Humanism from Propaganda: Chinese Photojournalism Practices between 1976 and 1988" (2017). SIUE Faculty Research, Scholarship, and Creative Activity. 65.

http://spark.siue.edu/siue_fac/65

This Article is brought to you for free and open access by SPARK. It has been accepted for inclusion in SIUE Faculty Research, Scholarship, and Creative Activity by an authorized administrator of SPARK. For more information, please contact magrase@siue.edu. 


\section{Cover Page Footnote}

A Turn to Realism and Humanism from Propaganda: Chinese Photojournalism Practices between 1976 and 1988

Shi Li

Department of Mass Communications, Southern Illinois University Edwardsville, Edwardsville, IL, USA

shli@siue.edu

Shi Li is an assistant professor at the Department of Mass Communications at Southern Illinois University Edwardsville. She received her doctoral degree in mass communications from Indiana University's Media School. Her research focuses on visual and international communication. 


\title{
A Turn to Realism and Humanism from Propaganda: Chinese Photojournalism Practices between 1976 and 1988
}

\author{
Abstract: China's photojournalistic field undertook great transformations in the \\ 1980s. While the conservatives continued to cling to the propagandistic doctrine, \\ a more progressive trend was emerging. The tension between these two forces \\ had its historical roots and would go on to shape the way Chinese \\ photojournalism developed. Based on archival research and in-depth interviews, \\ this paper revisits the history of Chinese photojournalism practices between 1937 \\ and 1988 and identifies the key features of these three periods: the wartime \\ propaganda of 1937-1949, the intensification of propaganda of 1949 - 1976, \\ and the transformation to realism and humanism in 1976-1988.
}

Keywords: Chinese photography; propaganda; humanistic photography; journalism reform; Bourdieu

\section{Introduction}

In 1982, American scholar Sandra Matthews (1982) wrote about her insights of the difference between Chinese and American photography:

\footnotetext{
Unlike the U.S., where documentary photography often serves to make visible the socially invisible, the emphasis in China is on a unified, positive, public face or image. Our news photography focuses on the visual spectacles of disaster; Chinese news photographs, which are few and far between, concentrate on guidelines for public behavior - the presentation of positive, instructional modes. (p. 6)
}

Hu Wugong, a photojournalist at Shaanxi Daily, would have echoed her words. Hu was in Ankang, Shaanxi Province on July 31, 1983 when a flood hit and killed 870 people. He captured some poignant moments as people fled their homes and police carried out rescue missions. However, none of the photographs was published in his newspaper. Upon his return to Xi'an, the first questions asked by his editor were, "Do you have any photo of a prosperous marketplace in Ankang? Or anything that shows people living normally?" Astonished, Hu proposed instead his disaster photographs. After being 
rejected by his newspaper which was not accustomed to disclosing any negative news, Hu turned to three State media outlets: People's Daily, Xinhua News Agency, and China Daily. The first two declined him, but China Daily not only accepted one of his photographs, but also displayed it on the front page (Figure 1). The next year, the same image earned Hu two national awards, one from the Photojournalism Society of China, and the other from the All-China Journalists Association (W. Hu, personal communication, July 22, 2012).

The drastically different treatments toward Hu's flood photograph shed light on the changing landscape of China's photojournalistic field in the early 1980s. While the conservatives continued to cling to the doctrine that news photographs must portray the positive, a more progressive trend was emerging. The tension between the two forces went on to shape the way Chinese photojournalism developed in the 1980s, until ideological control tightened in 1989. Situating this period within a theoretical framework developed by French sociologist Pierre Bourdieu, the study aims to understand the intricacies of what happened on China's photojournalistic field between 1976 and 1988 and explore how changes in the field revealed a social structural shift that led to the creation of a new space for the pursuit of realism and humanism in photojournalism practices. The significance of the study is twofold: first, it contains original research into the transformation of Chinese photojournalism practices from 1976 to 1988 , an area that is rarely examined, and constructs one of the first historical narratives of this era in English literature; second, it deconstructs this narrative by deploying a number of Bourdieu's thinking tools to critically interpret the tensions and forces behind the transpiration of the historical events. It is one of only a handful of studies that apply Bourdieu's theory in a Chinese context. The organization of the article also follows this logic: after a review of the propagandist tradition of Chinese 
media photography from the mid-1930s to the mid-1970s, the main body of the article offers a descriptive social history of Chinese photojournalism practices between 1976 and 1988. Then, in the discussion and conclusion section, using Bourdieu's conceptual tools, the article analyzes the complex interplay of power dynamics among individuals, official institutions, civil groups, and the larger political and economic structure that shaped the history of Chinese photojournalism.

\section{Theoretical Framework: Bourdieu, Journalism, and Photography}

Bourdieu (1993) defines a "field" as a dynamic space where agents and their social positions are located. A field's structure is determined by the relations between the positions agents occupy in the field. Those who occupy powerful positions tend to maintain its structure, while others try to transform it. A change in agents' positioning will entail a change in the field's structure (Johnson, 1993). An agent's position depends on the amounts of capitals he has, which come in four forms-economic, social, cultural, and symbolic. These are crucial sources of power that can be transformed from one form to another (Bourdieu, 1986). In particular, fields of cultural production are sites of contention where agents are always in conflict, struggling to take positions, competing for legitimacy, and attempting to establish their distinction through the accumulation of different types of capital (Bourdieu, 1993).

Both journalistic and photographic fields are subfields of cultural production, located in the larger field of power, which consists primarily of the political and economic fields (Bourdieu, 1996). The journalistic field is based on opposition between market forces, including circulation, audience size, advertising income and profit, and pure elements, such as independence, autonomy, industry principles and intelligent or investigative reporting (Benson \& Neveu, 2005; Bourdieu, 1998, 2005). On the other hand, in the photographic field, as part of the artistic field, agents' artistic statements, 
dispositions and actions all imply a kind of position-taking (Chan, 2013). According to Grenfell and Hardy (2007), the boundary of the photographic field has substantially blurred into other fields. Photojournalism is a case in point: it sits where the journalistic and the photographic fields converge. As such, it s a subfield where we can observe how rules of its two "parent" fields interact, compete, and negotiate to maintain or transform the structure of the "child" field. It is also where we can study how, at the top of the hierarchy, the field of power factors in during this dynamic process of maintenance versus transformation.

A few empirical studies have delved into the photojournalistic field using Bourdieu's theory. Lindblom (2015) discovers that Swedish photojournalists draw their professional ideology from the journalistic field, while relying on the photographic and artistic fields for its aesthetical norms. Zhong (2006) studies photojournalists in post1949 Taiwan, and finds that driven by political, economic and social factors, Taiwanese photojournalists have transformed their habitus: the 1949-1979 generation were controlled and conditioned by politics, the 1980-1990 generation were active witnesses and participants of social movements, and the 1991-2005 generation were workers on the assembly line of photojournalistic production in a commercial society.

In the People's Republic of China, the restructuring of political and social orders between 1976 and 1988 is undoubtedly one of the most crucial factors that led to new developments in the photojournalistic field during that time. Based on Bourdieu's interpretive framework, after constructing a history of Chinese photojournalism practices between 1976 and 1988, the study aims to answer three questions: 1) how was the position of the photojournalistic field related to the political structure? 2) How were the different constituents of the photojournalistic field related to each other? 3) How did 
the actual, particular agents within the photojournalistic field exercise their capitals to maintain or transform the field's structure?

\section{Methods}

The study relies on research into primary and secondary sources, as well as in-depth interviews. The most original research presents the history of Chinese photojournalism practices between 1976 and 1988. Although this period was well documented, a public archive has yet to be developed. Therefore, the research draws information from three personal archives. Li Yingjie, a member of the Modern Photo Salon, Pan Ke, a member of the Shaanxi Group, and Ren Shugao, a retired official from the China Photographers Association, shared with me their rich archives of their respective organizations that include photographs, brochures, exhibition catalogues, and trade journals. In addition, stacks of Chinese photography newspapers, magazines and books, published between 1979 and 1990, were purchased from second-hand bookstores. Organizing these diverse materials chronologically and reading them closely help me build a historical narrative of the era. In-depth interviews also contribute to the research. Between 2012 and 2015, six interviews, each lasting two to six hours, were conducted in Beijing and Xi'an. The informants include He Yanguang, Hu Wugong, Li Yingjie, Li Xiaobin, Pan Ke, Ren Shugao and Wang Wenlan. They remember the ethos of the time, the social, cultural, and political conditions in which they carried out their work. They represent different organizations, and speak for their personal experiences. Though not everyone was quoted, they all contributed to my research.

\section{Contextualizing Chinese Photojournalism's Propagandist Tradition}

According to The International Encyclopedia of Communication, photojournalism means "reporting visually" and serious photojournalists are committed to "recording history in as authentic a manner as humanly possible" (Newton, 2008). To understand 
how Chinese photojournalism evolved in the 1980s, it is important to first discuss its historical background.

\section{The Root of Chinese Media Photography: Wartime Propaganda (1937-1949)}

$\mathrm{Gu}$ (2009) traces the revolutionary origin of Chinese news photography to the 1930s when the Communist Army was waging guerrilla warfare with Japanese invaders in northern China. Roberts (2013) also examines the close relationship between war and propaganda in the history of Chinese photography. Based on their accounts, we can synthesize four factors that contributed to the establishment of Chinese media photography's propagandist tradition:

First, the Communist Party of China (CPC) was keen on recruiting experienced photographers and conducting workshops to teach ordinary soldiers camera skills, thus building a team of solider-photographers whose first and foremost responsibility was to serve the army. Between 1938 and 1948, approximately 30 workshops were organized, turning more than 500 soldiers into qualified photographers (Gu, 2009). Many of them became China's first generation media photographers in the post-war era, taking their propagandist style to different press outlets.

Second, between 1937 and 1949, by setting up a hierarchy of photography departments within different military legions, the CPC established a clear organizational structure among a large number of army photographers (Gu, 2009). This management system allowed the CPC to efficiently send orders, implement instructions, and make personnel adjustments from the top down. No longer an individual practice, photography became a team operation tightly controlled by the CPC.

Third, the CPC launched quite a few publications that featured photographs. Depicting the atrocities of the enemy and showcasing the bravery of the Communist Army, these publications were used to mobilize the soldiers and promote the CPC to the 
people. They laid the foundation of media photography in post-war China. In particular, Jin-Cha-Ji Pictorial, founded in 1942, was transformed to become the photography division of Xinhua News Agency, the biggest news agency in China (Gu, 2009).

Finally, theoretical guidance was developed to promote photography as a political tool. Sha Fei (1939) formulated the "weapon theory," emphasizing camera's function as a weapon to depict truth and serve politics. Mirroring reality was a main concern for many army photographers who believed that photography in its realistic form was most powerful in mobilizing people to support their Communist cause. To promote and preserve reality, Luo Guangda suggested that a photographer select the most typical and vivid moments to photograph (Gu, 2009). However, how a photograph could best represent reality remained situational. With many stories to cover and little film available during the war, photographers did not have the luxury to shoot freely as news unfolded. Many freely staged their subjects. In fact, Wu Qun even proposed that besides "capturing the moment," reenacting an event or directing their subjects to act for the camera was also acceptable (as cited in $\mathrm{Gu}, 2009$, p. 139).

Through these four elements, the CPC developed a fairly mature and complete propaganda system within the practice of the photographic medium between 1937 and 1949. This mechanism continued to operate as the foundation for China's media photography after 1949 .

\section{Deceptively Positive: When Media Photography Concealed Facts and Lied (1949-1976)}

Between 1949 and 1976 when Mao Zedong was the paramount ruler of China, the propaganda premise of Chinese media photography intensified. As part of the CPC's massive "thought control" program, photography was used in different publications to penetrate people's hearts and minds. At their worst, photographs published as news 
were reduced to visual lies, aiming to mislead people and convince them of the Communist leadership.

During this time, two photojournalistic malpractices evolved: first, an obsession to glorify socialist achievements through photographic manipulation; second, a repression of negative coverage, banning any photo that exposed social problems or natural disasters.

Examples were rampant throughout the Mao era. According to Wang Chunde (1956), approximately $80 \%$ of the photographs released by Xinhua in 1956 involved posing and staging. Some photographs even received compliments because they were "well orchestrated" (p. 42). The situation got worse during the Great Leap Forward Campaign (1958 - 1961). In his book Red Flag Photography Studio, Jin Yongquan (2009) described a "competition" among several Xinhua photographers who, in order to produce images that featured the most bountiful harvest, freely staged their subjects to sit, stand, or jump on growing paddy fields. Their hoax images, accompanied by exaggerated crop yield figures, were featured as facts in authoritative newspapers such as People's Daily and China Youth Daily.

In contrast to the proliferation of deceitful "positive" imagery, photojournalists failed to record many tragic events that actually occurred. For instance, the famine between 1958 and 1962 caused an estimate of 36 million deaths (J. Yang, 2012), but there was no public visual record of it. D. J. Clark (2012) spent six years searching for photos on the disaster, yet found only one that barely made a reference: an image of five ragged boys in 1958. Even this photograph, with such mild connotations, did not get published at the time. Similarly, during the Cultural Revolution (1966-1976), propaganda photos depicting positive scenes-people chanting revolutionary slogans, holding patriotic posters, studying's Mao's Little Red Book, performing loyalty 
dances - permeated the press, contributing to deifying Mao and extoling the era. The dark side remained a taboo. Most photographers obediently documented what the state wanted, bypassing all the tragic or brutal moments. Four decades after the Cultural Revolution ended, the number of photographs that surfaced to deliver an unsanitized view of the period remained extremely limited. Jiang Shaowu, Li Zhensheng, and Tsering Dorjee were among the few who managed to snip some frames off their film to preserve bleaker moments of this turbulent time.

Two factors led to the loss of journalistic ethics: first, an extrinsic influence from the Soviet Union; second, China's internal political and economic malaise.

Throughout the 1950s, China systematically imported the Leninist-Stalinist theory and principles of the press from the Soviet Union (J. Zhang, 2009). The Soviet model posits that the media should be controlled by the state and used as an instrument of social change and control. It should also reflect the official ideology and the ideal personality, avoiding any criticism against the state (Siebert, Peterson, \& Schramm, 1956). Meanwhile, Socialist Realism, the official Soviet artistic style, was promoted in China and achieved dominance in the artistic field (L. Yang, 1996). In 1954 and 1955, Xinhua News Agency sent some of its photographers to study at the official Telegraph Agency of the Soviet Union. When these photographers returned to China, they imparted their experience to fellow photographers (Yuan, 1957a and 1957b).

An even more important factor was China's political and economic system. During Mao's time, all Chinese media were owned and run by the state, and all media practitioners were state employees. The state provided them with cameras, film and other resources to carry out their work. Such exclusive reliance on the state inevitably relegated photojournalism to the service of the state. Furthermore, from the mid-1950s on, a succession of political movements, including the Hundred Flowers Campaign 
(1957), the Anti-Rightist Campaign (1957-1959), and the Great Leap Forward

Campaign (1958-1961), effectively silenced and tamed the opposition. It was normal for those who aired anything at odds with the official doctrine to receive severe penaltiesbeing removed from their jobs, or being sent for re-education at labor camps, etc. With a chilling effect these campaigns produced, by the time of the Cultural Revolution (1966-1976), Mao’s policies received little resistance. Even Li Zhensheng, arguably the most courageous photojournalist of his time who at great personal risk took and preserved many "negative" images of the era, admitted that staging and manipulating were common practices for him. "If you didn't do it, your photos would never be able to go through censorship and get published," Li said (personal communication, June 1, 2013). For example, on an assignment for the Heilongjiang Daily in late 1969, Li set up a scene in which two women read Mao's works to express their loyalty to the Chairman. The original picture was then cropped and retouched by the photographer to show an unobstructed and sharply focused portrait of Mao on a cleaned-up background before it appeared in the newspaper (Figure 2). The blurriness of the portrait of the leader would indicate a lack of respect, and the "messiness" of the room would project a negative perception of the heroic world of the peasants. It would have been impossible to publish the original image according to the prevailing editorial instructions of that time.

Between 1949 and 1976, Chinese news photography failed to bear witness to history, expose social ills, or capture the human condition. The deceptively positive photographs from this era reveal much truth about the nature of the propaganda state.

\section{Turning to Realism and Humanism: New Promises in a New Era (1976-1988)}

\section{"Seeking Truth from Facts": A Pursuit from the Official Press}

The turning point for Chinese news photography took place in 1976 when amateur 
photographers took up the job of professional photojournalists to surreptitiously document the April Fifth Movement in Tiananmen Square, despite official repression. It took them another two years to get their collective album People's Mourning published, an indication that political control started to relax in the middle of 1978 (Li, 2012). In December 1978, in a meeting that preceded China's economic reform, Deng Xiaoping (1978), the new paramount leader for the PRC, emphasized the need to "liberate thinking, free the mind, seek truth from facts, and move forward in unity”.

China's photojournalistic field immediately responded to Deng's talk by redressing problems with photographic authenticity. Two meetings held by Xinhua News Agency in 1978 and 1981 pointed out a new direction for Chinese photojournalism: "reflect the reforms of our time and progress of our society" (Y. Hu, 1990, p. 177). To achieve this objective, Xinhua asked its photographers to take photographs that were "timely, authentic, and lively" (Y. Hu, 1990, p. 177).

A discussion arose about what approach photographers should adopt to take photographs that could most accurately represent reality. Photography critics Yang Enpu (1979) and Long Xizu (1979) proposed the "capturing the typical moment" method, arguing that it would allow a photographer to pick the most typical example at its most revealing moment to tell the story. State leaders also offered their advice. Cultural official Zhou Yang (1979) told photojournalists: "When you photograph a family, you can pick a better one, but you can't photograph a non-existent, temporarily made-up one ... photography should stick to facts. Of course you can select and improve, but you should select a real one, not a fake one" (p. 37). Military leader Zhang Aiping (1979) told photographers to be more engaged in real life to understand what kinds of photos were essential in story-telling. He emphasized that if a moment was missed, photographers should not ask the subjects to re-enact. 
A leading voice on the topic was Jiang Qisheng, a researcher from Xinhua. Jiang was a long-term advocate for factual reporting. Between 1956 and 1964, he published extensively to berate photojournalists' practice of interfering with subjects or even manipulating facts (Jiang, 1982a, 1982b, 1982c, 1982d). Unfortunately, his efforts faltered. Like many other intellectuals, he was purged and put to silence during the Cultural Revolution. In the new era, he re-embarked on his unfinished mission by publishing a series of essays, including Why "Facts Serve Politics" is Absurd (Jiang, 1979). He advocated that "capturing" be the correct approach in photo-taking. As he became the first chairperson of the Photojournalist Society of China, a professional association for photojournalists established in 1983, his words became influential in the professional circle. Later, he established a few awards to promote factual reporting as the new standards for quality photojournalism (Y. Hu, 1990).

Through these efforts, by the late 1980s, most photojournalism practitioners reached an understanding that news photos should be "captured" rather than "posed" or "staged," and that they should be based on real people, events and situations. Although posed and fabricated news photographs continued to exist, once discovered, they were subject to public criticism. For example, in 1988, the Photojournalist Society of China withdrew an award given to Xinhua photographer Li Jin when two of his prize-winning photographs were discovered to be staged (Xiao, 1989).

From the late 1970s to the late 1980s, the photojournalistic field in China witnessed a change toward more respect for facts. It must be noted though, that Party Principles continued to be a fundamental tenet for the profession, and that the premise of media photography's role as a propagandistic tool remained unchanged. Part of the job of official photography researchers like Jiang Qisheng was to try to consolidate "Party Principles" with "realistic principle," which might be at odds with each other at 
times. In Jiang's rhetoric in the mid-1980s, the universal laws for photojournalism were its realistic and artistic qualities, while its service for politics and propaganda was uniquely Chinese. For Jiang, the two guiding principles for Chinese news photography were "the unity of its political nature and truthfulness" and "the unity of politics and art" (1985, p. 4). Jiang (1985) stated that as a revolutionary weapon, news photography must continue to serve the Party and the people, with revolutionary political ideology.

\section{Approaching Realism and Humanism: Quests from Two Civil Groups}

The political relaxation and subsequent improvements in official press photography undoubtedly inspired individual photographers. In the mid-1980s, many photographers started to form groups. One of the most important organizations that emerged to leave an impact on China's photography is the Modern Photo Salon.

In 1984, Wang Wenlan, a photojournalist at China Daily, decided to form a photo club. Working for the country's first national English-language newspaper launched in 1981 as a product of the open door policy, Wang was in the midst of the changes taking place in China's photojournalistic field. Prior to joining the newspaper in 1980, he was a propagandistic military photographer. At the paper, his Americaneducated editor Feng Xiliang let him realize that images of common people, not just leaders in important events, were also of great value and could receive prominent display (W. Wang, 1983). Hoping to share such ideas, he talked other photographers into forming a club. In March 1985, the Modern Photo Salon inaugurated.

Between May 14 and 24, 1985, the salon presented its first exhibition in Beijing's Sun Yat-sen Park, featuring over 170 photos by 124 photographers (L. Wang, 1987). Accompanying the exhibition was a catalogue lavishly printed in Hong Kong, unprecedented for any non-official photography organization in China. The man behind the making of the catalogue was Yang Shaoming, the second son of Yang Shangkun, a 
top official who became the Chinese president in 1988. Because of Yang's prominent family background, he quickly became head of the salon.

The next year 1986 marked the tenth anniversary of the end of the Cultural Revolution. The salon organizers decided to hold its annual exhibition in commemoration of the anniversary by showing over 200 documentary-style photographs taken between 1976 and 1986 to represent the social transformation in China during the ten years. The exhibition "Flashback: A Decade of Changes" opened to the public in the National Art Museum of China on April 5. In September, the salon published a book with the same title, categorizing the photographs into six sections: Crying Out, Changes, Struggling, Variety, Problems, and Expectation. In the preface, the photographers declared: "We have refrained from blindly recording events, but focusing our lenses on human experience and thought...we have endeavored to capture the new realities from fresh angles in an effort to probe for answers to the challenges of our times" (S. Yu \& S. Yang, 1986, p. 3).

The exhibition made a splash in China's photographic field. It was the first attempt to visually organize Chinese social history in an unembellished fashion, thus demonstrating the power of news and documentary photography in preserving memory and reconstructing a more realistic past. It also pushed the official boundary, real or imaged, for what kinds of images were suitable for the public. At that time, negative news was hard to get published, but the Modern Photo Salon did not choose to censor itself. The "Problem" section of the exhibit included photos that referred to xenophilia, sexism, commercialism and superstition. More importantly, the Cultural Revolution, a topic that remains sensitive in China even today, was confronted visually. The show presented a photo by Li Xiaobin titled The Petitioner (Figure 3). It was a portrait of an old man dressed in a torn jacket, with three Mao badges clipped on his chest. His chin 
lightly lifted, lips half opened, wrinkled face and tired eyes expressing a complex feeling that seemed to be a mixture of anxiety, helplessness, disturbance and yearning, all at the same time. Li took the photo near Tiananmen Square in November 1977.

Petitioners were a special population in Beijing: in the late 1970s, a large number of individuals who were unfairly treated during the Cultural Revolution and who failed to find redress at the local level traveled to Beijing with the hope to plead to the higher authorities. Unable to afford a decent living in Beijing, many of them became homeless, often wandering around Tiananmen Square. The Petitioner offers a glimpse of one such individual, an archetype for hundreds of thousands at the peak of the petitioners' wave in Beijing. After taking the photograph, Li did not dare to get his film developed in a lab until February 1978. Back then, people were still discouraged or even forbidden from photographing anything negative, let alone documenting something as controversial as "the petitioner." In the following years, Li kept this photograph private. He did not believe he was able show the picture publicly until Yang asked him to submit entries for the "Flashback" exhibition in 1986. Yang wanted something solid, so Li showed him The Petitioner. Yang immediately approved it (X. Li, personal communication, June 27, 2010).

Yang's outright acceptance surprised Li, who thought it might take at least 20 years before the photograph could be openly exhibited (X. Li, personal communication, June 27, 2010). Indeed, while extraordinary progress had been made in Chinese society since 1976, the authorities were slow to allow public exposure of negative information, especially on visual terms. In 1979, when eminent cultural official Zhou Yang (1979) visited the China Photographers Association, he said,

Many art forms can criticize reality, but it seems photography cannot. It can focus only on the positive. I would like to assign photographers a task: photograph the unjust and the negative, and send such photos as internal materials to the Central 
Party Committee. Although situation in our country is turning better, there remain many difficulties and problems. Shouldn't photography reflect some of these?

What some foreigners do is certainly bad. They look for the dark side exclusively and cover only the negative. Why shouldn't we take the initiative to photograph the negative, and use the photographs as a reference for leaders to improve their work? We should do this, not for open publication, but for internal reference. (p. 38)

Although permitting "negative photos" for internal reference was in itself a step forward, it also meant that in 1979 , the authorities were not ready for the public to confront problems through photographs. The first major breakthrough came in 1983 when China Daily published Hu Wugong's photograph of the Ankang flood, but China Daily is an English-language newspaper with foreigners as its target readership. People's Daily, Xinhua, and Shaanxi Daily all rejected the same photograph, indicating that the mainstream press still considered photos of disasters unprintable. The quest for transparency in news photography became more urgent in 1984 when Hu's photo received the first award given by the newly-established Photojournalist Society of China under the leadership of Jiang Qisheng. In 1985, a series of photographs titled Out to the Battlefield (Figure 4) by Hou Dengke and Pan Ke that captured the tearful moments of a young lady seeing her soldier fiancé off at a train station on his way to the battlefield sparked a heated debate, after China Youth Daily published it. Supporters applauded the work for its truthful depiction of human emotions, while opponents criticized it for its lack of revolutionary optimism, fearing that it might shake the army's morale (Xia, 2007). That same year, Hu Yaobang, the CPC's Secretary General, suggested in a speech that newspapers devote $80 \%$ of the space to "achievements, bright aspects, and things good" with the remaining $20 \%$ covering "shortcomings, dark aspects and criticism" (Mann, 1985, sec. Part I, b33).

It was under such a media environment that the Modern Photo Salon presented Li's The Petitioner. Mild as it might appear, the image pointed directly to two critical 
problems that touched a nerve of China's political leadership: Mao's Cultural Revolution that caused the old petitioner's misery, and the current judicial system's slow response in handling the seemingly endless cases like this one. Yang's family background allowed him to understand the intricacy of China's top political leadership, as well as the art to secure its approval for the photo. Li Xiaobin recalled the key moment when any possible criticism toward this photograph was warded off,
Many journalists attended the exhibition's opening ceremony. National leaders Wang Zhen, Xi Zhongxun and Bo Yibo were also invited... Yang Shaoming and Wang Liping accompanied the three senior statesmen to tour the exhibition. When they reached this image, Yang told Wang Zhiping that the photograph expressed a rejection to the Cultural Revolution, of which the three senior comrades were also victims. At that time, the only comment on the photograph was 'great!' There were journalists all around the three senior leaders when they lauded the image. That moment essentially prevented any opposing voices from arising (personal communication, June 27, 2010).

After the "Flashback" project, the Modern Photo Salon organized a weeklong seminar on realistic-style photography in Zhuhai, a city in Guangdong province, in July 1987. About 50 of China's most influential photographers, editors, and critics attended. The event witnessed a small clash between the raw, humanistic approach by some photographers and the political nature of official news media. Wu Jialin (2007) a photographer based in Yunnan province, recalled his encounter with Jiang Qisheng. After Wu showed some photos from his "Mountain Folk in Yunnan" series, Jiang, already a more progressive figure within the establishment, criticized that $\mathrm{Wu}$ focused too much on poverty and backwardness. Jiang suggested Wu select more beautiful aspects of the people and the region to document. $\mathrm{Wu}$, on the other hand, believed he must work from what he observed, and refused to let a pre-set ideological frame confine his understanding of reality. 
Some photographers complained at the seminar that China's censorship system stifled their creativity, to which Yang responded, "Whether our work can get published or not, let's take the picture first." Yang's words quickly spread around, reminding many photographers not to leave a blank page in history (Y. Li, July 12, 2012).

At this point, the Modern Photo Salon, which started out as a civil organization, had attained significant status in China's photographic field. In 1988, the salon made a number of strategic moves, including renaming itself to the Contemporary Photography Society, launching an internally-circulated magazine titled Communication $\bullet$ Contact to feature writings by its members, and expanding its activities internationally. All these signified that Yang was ready to take his organization to a new level. That year, Yang's father Yang Shangkun became the Chinese President.

While the Modern Photo Salon took a top-down approach to break taboos through its direct negotiation with the country's top leaders thanks to Yang Shaoming's rich political and social capital, another group of photographers, known as the Shaanxi Group, advocated realism and humanism through a bottom-up crusade.

Based in the northwestern province of Shaanxi, this group consisted of nine photographers, ${ }^{1}$ a few of whom have already been mentioned earlier, including $\mathrm{Hu}$ Wugong, Hou Dengke and Pan Ke. Unlike the Modern Photo Salon whose organizers were mostly elites — son of the Chinese President, photojournalists from major national publications in Beijing - the Shaanxi Group retained a grassroots quality. Coming from modest backgrounds, its members had received little formal education. Among them, Hu and Pan were the only photojournalists, for the local Shaanxi Daily and the Shaanxi Pictorial respectively. Others were railroad workers or local clerks.

Between 1982 and 1985, these like-minded photographers formed a loose circle known as the "Shaanxi Group." Several of them started to attract national attention: In 
1984, Hu received two major awards for When the Flood Hit; in 1986, Pan Ke and Hou Dengke shared a second prize in a national competition for Out to the Battlefield, which led to a heated discussion on whether images displaying sadness of soldiers as they left home for war were appropriate for publication.

From these two examples, humanism, an enduring theme of the group's work, surfaced. As a philosophical and ethical stance, humanism exists in various forms and schools. But despite the differences, its core value emphasizes the agency of human beings and rejects blind obedience to authority, whether religious or political (e.g., Norman, 2013; Walter, 1997). By turning their lens to human beings—individuals suffering amid a mighty natural disaster or private emotions beneath the glorified image of war-the Shaanxi Group adopted a human-centered approach to photography, prioritizing human well-being over party ideology.

If at this point their humanistic inclination was still a spontaneous reaction to what appeared in front of their camera, what they did later no doubt demonstrated a consciously-chosen value judgment influenced by their own experiences and informed by thoughts prevalent in China's intellectual life in the mid-to-late 1980s.

Humanistic themes started to emerge in China's literary field in the early 1980s. From late 1982 to early 1983, the notion of Marxist humanism and socialist alienation attracted intense debate in the political field. The Party's Maoist hard-liners quickly repressed such ideas by ousting its major proponents Zhou Yang and Wang Ruoshui, and launched the Anti-Spiritual Pollution Campaign in late 1983 to resist "bourgeois thoughts." Nonetheless, humanistic thought prevailed among China's intellectuals through the introduction of western literary and philosophical works by authors such as Immanuel Kant and Jean-Paul Sartre (J. Wang, 1996). 
Influenced by these thoughts, the Shaanxi Group organized a national symposium on photographic aesthetics in Xi'an in 1986. They took the opportunity to present works in their first collective exhibition "Winds from the Northwest." Hou Dengke, on behalf of the group, delivered at the symposium what could be considered the group's artistic manifesto, a treatise titled Current Reality and Our Thoughts (Qin, 1986). It deplored the standard of many photography contests in judging photographsnot based on their artistic or humanistic merits, but on how well they illustrated pompous political slogans, often by adopting visual clichés, or even by having tactfullycrafted titles and captions. It also condemned the dogmatic interpretation of Russian theorist Nikolai Chernyshevsky's concept "beauty is life," which served as a popular guideline for artistic creation in China yet often led to a romanticized portrayal of reality. The talk pointed to what they believed to be the source of the problems: a conservative inclination, residues from history, and photographers' deficiency in producing innovative work.

To combat what they considered the ills of official photography and promote their standards of quality photojournalism, they decided to organize a national photography competition. They conceptualized that the project would be a visual chronicle of Chinese history since 1949, consisting of photographs honestly captured with a humanistic dimension. They set up three grand awards for photographers whose body of work each covered a ten-year time frame. The project was named "The Hard Journey" to represent the path the country had gone through since 1949 . Their friend Ren Shide helped raise 680,000 Chinese yuan for the project (W. Hu, personal communication, July 22, 2012).

By the end of 1987, the competition had received over 20,000 photographs from 1,735 photographers (Editorial Committee, 1988). A few of the Shaanxi Group 
members pre-screened all entries before handing over their selection to a 29 -member jury, which was carefully chosen to represent both the conservative and the progressive voices in the field, so that the results would appear most fair and authoritative (W. $\mathrm{Hu}$, personal communication, July 22, 2012).

Yang Shaoming and a few others from the Modern Photo Salon were on the jury, representing the progressive voices. Jiang Qisheng, the official photojournalism reformist, was also invited. By this time, however, he had become "old-school" in the eye of the Shaanxi Group. Jiang's notion of photojournalistic authenticity was limited to the approach of image-taking — that a photojournalist should not pose or stage the subject, and that no doctored photograph was allowed. By 1987, most Chinese photojournalists had accepted this as a norm, and Jiang believed the problem with photojournalistic veracity had been largely resolved. For the Shaanxi Group, however, truth in photojournalism went far beyond this. It involved more autonomy on the part of the photographer, and that subjects in photographs should not be used to illustrate an ideology or a predetermined political point of view, but should instead be looked at as individuals shaped by their own historical and social circumstances.

These two views on what constitutes photojournalism authenticity reveal a fundamental difference between the official establishment and the civil group in their respective pursuit of realism. Realism is a complex idea. In art and literature, it refers at first to a method that leads to "an exceptional accuracy of representation," and later to "a commitment to describing real events and showing things as they actually exist" (Williams, 1985, p. 259). However, depicting reality with complete objectivity is impossible, as Williams (1985, p. 260) states, "There are many real forces-from inner feelings to underlying social and historical movements—-which are either not accessible to ordinary observation or not at all represented in how things appear, so that a realism 
'of the surface' can miss important realities.” In representing such realities, both sides inevitably brought in their own interpretive framework or "habitus." The conservatives, acting as agents of the state-owned press, adopted an official ideological framework and "captured" the fitting moment to tell the story. The progressives not only improved methodological and technical rigour, but also rejected political conditioning and embraced a more independent and humanistic approach.

Photographs that emerged from "The Hard Journey" project exemplified this independent and humanistic approach. In March 1988, a selection of 260 photographs from the competition was shown in the National Art Museum of China. More than 100,000 visitors crowded the exhibition halls over ten days, making "The Hard Journey" one of the most successful photography shows in China. What drew most attention were the three grand prize winners: Shi Panqi on "The Start: 1949-1958," Li Zhensheng on "The Turmoil: 1966-1976" and Li Xiaobin on "The Change: 1976-1986." The three bodies of work touched upon some of the most sensitive topics, particularly Li Zhensheng's photographs of the Cultural Revolution (Figure 5). Nothing close to the "red, bright and shining" version of the infamous era, Li's imagery provoked viewers with some very poignant and disturbing moments during the catastrophe, including Mao's cult of personality, public humiliation, and senseless violence. In addition, $\mathrm{Li}$ Xiaobin's series included not just The Petitioner, but also photographs of Beijing's Democracy Wall in the late 1970s, another controversial subject. Equally revealing was a section of the exhibit that featured seven fake news photos, including one that depicted a young mother trying to breastfeed a wounded solider on the Laoshan battlefront during the Sino-Vietnamese Conflicts in the 1980s.

For the Shaanxi Group members, it was a moment of pride when they saw their motto "respect history, support innovation, encourage individualism, promote 
democracy" printed on a large panel leading to the exhibition. A few months later, the exhibition catalogue Forty Years in Chinese Photography was published. The preface showed a strong humanistic concern:

Human beings are the subject of history, and that of photography as well. Forty Years of Chinese Photography aims to focus on people, and this has become the basis for our selection of photographs. Our people were liberated from feudalism, yet then submerged by the misery of blind worship. As a result, although our nation rose from difficulty, we still fell into the historic tragedy of madness. A wide spectrum of social practices granted our people a rich and complex spiritual world. We seek to use a kind of cultural awareness to summarize and reflect on the fate, the consciousness, the spirit and the hope of our nation, one that has experienced various trials and tribulations but never given up. (Editorial Committee, 1988, para. 6)

While the exhibition was on view in Tokyo, Japan between May 26 and June 7, 1989 (W. Hu, 1989), authorities in Beijing cracked down on the student protests in Tiananmen Square. Political control tightened afterwards, and plans for the exhibition to travel to Europe fell through.

The utopian vision of the future faded, replaced by an escalating consumer culture. Chinese photojournalism reforms in the 1990s would face the dual challenge from political censorship and commercialism. The journey toward realism and humanism had indeed been hard.

\section{Discussion and Conclusion}

The Chinese photojournalistic field between 1976 and 1988 demonstrated a complex, often diverged, path from propaganda to realism and humanism. To interpret this history, the article applies Bourdieu's three-step analytical approach (Bourdieu \& Wacquant, 1992, p.104-7): 
1, Analyze the position of the field vis-à-vis the field of power;

2, Map out the objective structure of relations between the positions occupied by agents who compete for the legitimate forms of specific authority of which the field is a site;

3, Analyze the habitus of agents; the systems of disposition they have acquired by internalizing a deterministic type of social and economic condition.

\section{1) The Photojournalistic Field and the Field of Power}

It is clear that in relation to the field of power, a fundamental structural change did not occur on Chinese photojournalistic field between 1976 and 1988. The photojournalistic field continued to be an integral part of China's larger political and ideological underpinning. Although Bourdieu notes that each field is relatively autonomous (Johnson, 1993), the peculiarities of modern Chinese history rendered media photography at the service of politics. In the 1930s, it was established as a subfield embedded within the military field. Similar to other military subfields, such as strategic planning or logistics, media photography only existed in support of war missions. In 1949, with the founding of the PRC, the photojournalistic field was "handed over" from the military to the political field, but the hierarchical order remained intact, because the military commanders now became political leaders. In the following years, a succession of political campaigns intensified the propagandist nature of media photography, since it was used as a governing and controlling tool more than ever. In the 1970s, changes in the field of power provoked changes within the photojournalistic field, but the photojournalistic field's overall relation with the political field remained intact. Agents had to operate within the parameters defined and approved by the state. The cultural platforms where they carried out their work, such as media outlets, professional associations, photography contests and exhibition venues, were all owned and controlled by the state. 


\section{2) The Structural Topography of the Photojournalistic Field}

In contrast to a fixed, stable state between 1937 and 1976, the photojournalistic field's structure started to see some changes in its topography from the late 1970s. Within the official realm, the normative journalistic principle — a respect for facts and accuracywere introduced. The Photojournalism Society of China and its leader Qiang Qisheng advocated "capturing" as the right approach in photo-taking to achieve journalistic authenticity. Along with the longstanding Party principles, the technical approach to "truth" became a new rule of the official photojournalistic field.

Outside the official establishment, with the emergence of civil groups such as the Modern Photo Salon and the Shaanxi Group, an unofficial realm of photojournalistic production, previously non-existent, was created. By reinterpreting and representing truth and reality not from a political perspective but from a humanistic perspective, these new comers attempted to transform the structure of the photojournalistic field. To do so, they relied on apparatus in the artistic field, such as organizing exhibitions in galleries and museums, publishing artistic statements and photo albums, holding contests and giving awards. The photojournalistic field's dual belonging to the journalistic and artistic fields allowed them to draw cultural and symbolic capitals from the artistic field to apply to the photojournalistic field, thus giving them significant positions in the field.

\section{3) Key Agents on the Photojournalistic Field and Their Habitus}

Bourdieu (1993) suggests that key agents in cultural fields are those whose reputations and institutional positions empower them to evaluate which work is valuable. They do so through "the power to consecrate and to win assent when he or she consecrates an author or a work - with a preface, a favorable review, a prize, etc" (p. 42). Other agents 
may honor these leaders by demonstrating their allegiance, or contest these leaders' authority by challenging their definition of the cultural field and its established aesthetics. Habitus is a more ambiguous concept. It can be understood as the deeply ingrained, socialized norms or tendencies that guide one's behavior and thinking. It is the physical embodiment of capital (Bourdieu \& Wacquant, 1992).

Between 1937 and 1949, photojournalists - agents in the photojournalistic field — were in essence soldiers. Their first obligation was to execute commands from the top, not to observe guidelines of photojournalism. After 1949, the authoritative political system and a series of political movements rendered photojournalists to conceal facts, aggrandize achievements, or lie with their images. If they did not do so, they may not be able to gain more cultural or symbolic capital (e.g., get published), or may even lose the field positioning and capital they had (e.g. removed from their jobs).

Between 1976 and 1988, a number of key agents emerged, who more or less changed the photojournalistic field's structural topography. They included Jiang Qisheng and Yang Shaoming. Jiang accumulated great cultural capital through his long career as a photography researcher at Xinhua News Agency since the 1940s. In the early 1980s, Jiang contributed to founding the Photojournalism Society of China and became its first chairperson, helping to raise the status of photojournalism. His reputation and position authorized him to organize seminars and competitions, through which the long practice of posing and staging was rejected, and "capturing" as a preferred approach was established. Although by 1988, he was no longer considered a renovator in the eye of the more progressive Shaanxi Group, his influence persisted. When the Shaanxi Group tried to promote new values in photojournalism through their "The Hard Journey" competition, the group had to seek help from Jiang and invite him as a juror, 
indicating the cultural and symbolic capital Jiang possessed, as well as the young and local Shaanxi Group's lack of such resources.

Yang Shaoming embodied the power of social capital. When he joined the Modern Photo Salon in 1984, he was an unknown photojournalist, but his prominent family background quickly gained him leadership in the salon. His social capital also prompted the salon's quick rise within the photographic field through the various activities he organized.

Agents could be individuals as well as institutional actors. While Jiang and Yang were important individual agents who enacted agency through the institutions they represented, the Shaanxi Group represented a grassroots force that tried to compete for cultural capital through different means - their photographs, articles, talks, contests and exhibitions. Economic capital was also an essential ingredient to its success. Being a group of local photographers, it did not have much social or cultural capital at its disposal. However, it was able to raise 680,000 Chinese yuan - an astonishing figure in China then — from advertisers to support the "The Hard Journey" project. This money allowed $\mathrm{Hu}$ Wugong to travel to Beijing to persuade individual photographers to enter the competition, to host jury members from around China, to pay rental fees for exhibition venues, and to award the prize recipients. The popularity of the exhibition established the group as a new cultural leader in China's photojournalistic field.

In sum, this article constructs an original historical narrative of Chinese photojournalism practices between 1976 and 1988. The application of Bourdieu's theory offers a wide perspective for us to explore the transformation of Chinese photojournalism practices and to discern the structural mechanism hidden beneath such transformation. However, the research has its limitations. Focusing on photojournalism practices and analyzing only a few photographs, it does not address the important issue 
of how content of media photographs evolved over time. Future studies may apply content analysis to a large number of images to answer this question. Future research may also use the current research as a starting point to examine how Chinese photojournalism has developed since 1989 to the present time in response to the changing media landscape, global economy, and on-going digital revolution. Finally, it must be noted that media photography in other countries can also be propagandist and purposefully misleading, including the Farm Security Administration images in the United States, or much war photography. The results of this research therefore also provide information for future international comparative studies in this field.

\section{Notes}

1 There is no precise number of the group members. But its "core members," alphabetically, included Bai Tao, Hou Dengke, Hu Wugong, Jiao Jingquan, Li Shaotong, Li Shengli, Pan Ke, Qiu Xiaoming and Shi Baoxiu. 


\section{Bibliography}

Benson, R. D., \& Neveu, É. (2005). Bourdieu And The Journalistic Field. Polity. Bourdieu, P. (1986). The forms of capital. In J. G. Richardson (Ed.), Handbook of Theory and Research for the Sociology of Education (pp. 241-258). New York: Greenwood Press.

Bourdieu, P. (1993). The Field of Cultural Production. (R. Johnson, Ed.) (1st edition). New York: Columbia University Press.

Bourdieu, P. (1996). The Rules of Art: Genesis and Structure of the Literary Field. Stanford University Press.

Bourdieu, P. (1998). On television and journalism. Pluto Press.

Bourdieu, P. (2005). The political field, the social science field, and the journalistic field. In R. Benson \& E. Neveu (Eds.), Bourdieu and the journalistic field (pp. 29-47). Malden, Massachusetts: Polity. Retrieved from http://wxy.seu.edu.cn/humanities/sociology/htmledit/uploadfile/system/2010082 5/20100825224221224.pdf

Bourdieu, P., \& Wacquant, L. J. D. (1992). An Invitation to Reflexive Sociology (1st ed.). University Of Chicago Press.

Chan, P. (2013). The Institutionalization and Legitimatization of Guohua: Art Societies in Republican Shanghai. Modern China, 39(5), 541-570. https://doi.org/10.1177/0097700413491714

Clark, D. (2012). A Single Image of Famine in China. In G. Batchen, M. Gidley, N. K. Miller, \& J. Prosser (Eds.), Picturing Atrocity: Photography in Crisis (pp. 92104). London: Reaktion Books. 
Deng, X. (1978). Liberate Thinking, Seek Truth from Facts, Look Forward in Unity. Presented at the Closing Session of the Working Conference by the Central Committee of the Communist Party of China, Beijing.

Editorial Committee. (1988). Afterword. In Zhongguo Sheying Sishi Nian: “Jianju Licheng” Quanguo Sheying Gongkaisai Youxiu Zuopin Huiji [Forty Years in Chinese Photography: A Collection of Works from "The Hard Journey" National Photography Open Competition]. Xi'an: Shaanxi Renmin Meishu Chubanshe.

Grenfell, M., \& Hardy, C. (2007). Art Rules: Pierre Bourdieu and the Visual Arts. Oxford ; New York: Bloomsbury Academic.

Gu, D. (2009). Zhongguo Hongse Sheying Shilu [Historical Record of Chinese Red Photography]. Taiyuan: Shanxi Renmin Chubanshe.

Hu, W. (1989). Ribenren Yanzhong de Zhongguo Sheyingzhan [Chinese Photography Exhibition in Japanese Eyes]. Xinwen Shijian [News Practices], (09), 39-40.

Hu, Y. (1990). Wo Guo Shinian Xinwen Sheying Gaige de Huigu yu Sikao [Revisiting and Rethinking the Ten-year Photojournalism Reform in my Country]. Tu Wen Bingzhong, Liang Yi Qifei - Di Si Jie Quanguo Xinwen Sheying Lilun Nianhui Lunwen Ji [Emphasizing Both Pictures and Words - A Collection of Papers Presented at the Fourth National Photojournalism Theory Annual Conference], 21.

Jiang, Q. (1979, March). “Shishi Wei Zhengzhi Fuwu” Weishenme Shi Huangmiu de [Why "Facts Serve Politics" is Absurd]. Zhongguo Sheying [Chinese Photography], 46-47.

Jiang, Q. (1982a). Duiyu Xinwen Sheying Zhenshixing Ji Youguan Wenti de Lilun Renshi [Theoretical Understanding of Photojournalistic Truthfulness and Other 
Related Issues]. In Xinwen Sheying Lunji [A Collection of Essays on

Photojournalism] (1st ed., pp. 293-356). Beijing: Xinhua Chubanshe.

Jiang, Q. (1982b). Fan Baibu Douzheng Zhong de Jige Wenti [Several Questions

Regarding the Battle against Photographic Manipulation]. In Xinwen Sheying

Lunji [A Collection of Essays on Photojournalism] (1st ed., pp. 184-194).

Beijing: Xinhua Chubanshe.

Jiang, Q. (1982c). Lun Bu Ganshe Duixiang de Sheying [On Photography That Doesn’t Interfere with the Subject]. In Xinwen Sheying Lunji [A Collection of Essays on Photojournalism] (1st ed., pp. 280-292). Beijing: Xinhua Chubanshe.

Jiang, Q. (1982d). Women Yaozhuo Cujin Pai —Du "Zuzhi Changmian Bu Zhenshi Ma" Yiwen Zhihou [We Need to be Promoters - My Response on the Article "Isn't Setting Up a Scene Realistic"]. In Xinwen Sheying Lunji [A Collection of Essays on Photojournalism] (1st ed., pp. 223-232). Beijing: Xinhua Chubanshe. Jiang, Q. (1985). Xinwen Sheying de Yiban Guilv yu Zhongguo Tese

[Photojournalism's General Laws and Chinese Characteristics]. A Collection of Papers Presented at the 1985 National Photojournalism Theory Annual Conference, 1-6.

Jin, Y. (2009). Hongqi Zhaoxiang Guan: 1956-1959 Zhongguo Sheying Zhengbian [Red Flag Photo Studio: Debates on Chinese Photography between 1956-1959] (1st ed.). Beijing: Jincheng Chubanshe.

Johnson, R. (1993). Editor's Introduction: Pierre Bourdieu on Art, Literature and Culture. In P. Bourdieu, R. Johnson (Ed.), The Field of Cultural Production (1st edition). New York: Columbia University Press. 
Li, S. (2012). The April Fifth Movement: Marking the Rise of Citizen Photojournalism in the People's Republic of China. Visual Communication Quarterly, 19(2), 6884. https://doi.org/10.1080/15551393.2012.682851

Lindblom, T. (2015). Tracing Changes in the field of Photojournalism-The Swedish field. Presented at the NordMedia Conference, Copenhagen, Demark. Retrieved from https://www.researchgate.net/profile/Terje_Lindblom/publication/281492811_T racing_Changes_in_the_field_of_Photojournalism__The_Swedish_field_Divisi on_Journalism_Studies/links/55eb030f08ae3e12184693b3.pdf

Long, X. (1979, May 20). Sheying de Aomi Zai Nali - Zhua Shunjian [Where is the Secret of Photography - Capturing the Moment]. Zhongguo Sheying [Chinese Photography], 51-52.

Mann, J. (1985, May 7). Experiment With Liberalization Suddenly Ends: China Tells Press It Must Follow the Party Line. Los Angeles Times (1923-Current File), p. b33.

Matthews, S. (1982). Chinese Photography: Notes toward a Cross-Cultural Analysis of a Western Medium. Afterimage, (9.6), 4-7.

Newton, J. H. (2008). Photojournalism. In W. Donsbach (Ed.), The International Encyclopedia of Communication. Blackwell Publishing. Retrieved from http://www.blackwellreference.com.libproxy.siue.edu/subscriber/tocnode.html?i d=g9781405131995_chunk_g978140513199521_ss35-1

Norman, R. (2013). On Humanism (2 edition). Routledge.

Qin, Y. (1986). Xianzhuang yu Sikao [Current Reality and Our Thoughts]. In Sheying Meixue Chutan [Initial Exploration of Photographic Aesthetics] (pp. 138-162). Xi'an: Shaanxi Renmin Meishu Chubanshe. 
Roberts, C. (2013). War and Propaganda. In Photography and China (pp. 91-120). London: Reaktion Books.

Sha, F. (1939). Preface II. In Y. Wu, Sheying Changshi [Common Knowledge on Photography]. Jin-Cha-Ji Junqu Zhengzhibu Sheyingke [Jin-Cha-Ji Military Zone Photography Division].

Siebert, F. S., Peterson, T., \& Schramm, W. (1956). Four Theories of the Press: The Authoritarian, Libertarian, Social Responsibility, and Soviet Communist Concepts of what the Press Should be and Do. University of Illinois Press. Walter, N. (1997). Humanism: What's in the Word? London: Rationalist Press Association Ltd.

Wang, C. (1956). Dui Sheying Baodao Zhong Zuzhi Jiagong de Yijian [Opinions on Posing and Staging in Photographic Reports]. Sheying Yewu [Photography Business], (2), 42.

Wang, J. (1996). High Culture Fever: Politics, Aesthetics, and Ideology in Deng's China. Berkeley: University of California Press.

Wang, L. (1987). The Modern Photo Salon / Liang Nian Lai Jianli de Quanguoxing Sheying Tuanti Jieshao [An Introduction to the National Photography Associations That Were Founded in the Last Two Years]. In Zhongguo Sheying Nianjian Bianjizu [China Photographic Annual Editorial Team] (Ed.), Zhongguo Sheying Nianjian: 1984-1985 [China Photographic Annual 1984-1985] (pp. 144-147). Beijing: Zhongguo Sheying Chubanshe.

Wang, W. (1983). Wo Zenyang zai "Zhongguo Ribao" Gao Xinwen Sheying [How I Operate on Photojournalism at China Daily]. A Collection of Papers Presented at the 1983 National Photojournalism Theory Annual Conference, 515-521. 
Williams, R. (1985). Keywords: A Vocabulary of Culture and Society (Rev Sub edition). New York: Oxford University Press.

Wu, J. (2007, March 5). "Shanliren” Zouguo de "Shiguang” — Fang Wu Jialin [“Mountain Folk" Went Through "Time" —An Interview with Wu Jialin. Retrieved from http://blog.sina.com.cn/s/blog_3e740a02010007jz.html Xia, Y. (2007, December 5). Hou Dengke: Jiangshu “Tamen” de Lishi [Hou Dengke: Telling “Their” History]. Zhongguo Qingnian Bao [China Youth Daily]. Retrieved from http://zqb.cyol.com/content/2007-12/05/content_1982791.htm Xiao, S. (1989). Rongyu de Kaoyan [A Test of Honor]. Zhongguo Jizhe [Chinese Journalists], (01), 20-21.

Yang, E. (1979). Tichang "Xuan, Deng, Qiang” (Advocate for "Selecting, Waiting and Capturing." Zhongguo Sheying [Chinese Photography], 47-49.

Yang, J. (2012). Tombstone: The Great Chinese Famine, 1958-1962. (E. Friedman, S. Mosher, \& J. Guo, Eds., S. Mosher \& J. Guo, Trans.). New York: Farrar, Straus and Giroux.

Yang, L. (1996). “Socialist Realism” versus “Revolutionary Realism plus Revolutionary Romanticism.” In H. Chung, M. Falchikov, B. S. McDougall, \& K. McPherson (Eds.), In the Party Spirit: Socialist Realism and Literary Practice in the Soviet Union, East Germany and China (pp. 88-105). Amsterdam-Atlanta, GA: Rodopi B.V.

Yu, S., \& Yang, S. (1986). Flashback: A Decade of Changes. Beijing: China Photographic Publishing House.

Yuan, L. (1957). Zai Sulian Sheying Shixi de Tihui [Experiences on My Photography Internship in the Soviet Union]. Shanghai Renmin Meishu Chubanshe. 
Zhang, A. (1979, May 20). Zai Shoudu Sheyingjie Yingchun Chahuahui shang Zhang Aiping Tongzhi de Jianghua [A Talk by Comrade Zhang Aiping in the Capital's First Spring Tea Party]. Zhongguo Sheying [Chinese Photography], 38.

Zhang, J. (2009). Zhong E Xinwen Wenti Bijiao [A Comparision between Chinese and Russian Journalistic Texts]. Bejing: China Social Sciences Press.

Zhong, Y. (2006). The Formation of Habitus and Taste of Taiwan's Photojournalists after 1949. In Chinese Communication Society. Taiwan. Retrieved from http://ccs.nccu.edu.tw/paperdetail.asp?HP_ID=46

Zhou, Y. (1979, May 20). Zai Shoudu Sheyingjie Yingchun Chahuahui shang Zhou Yang Tongzhi de Jianghua [A Talk by Comrade Zhou Yang in the Capital's First Spring Tea Party]. Zhongguo Sheying [Chinese Photography], 37. 